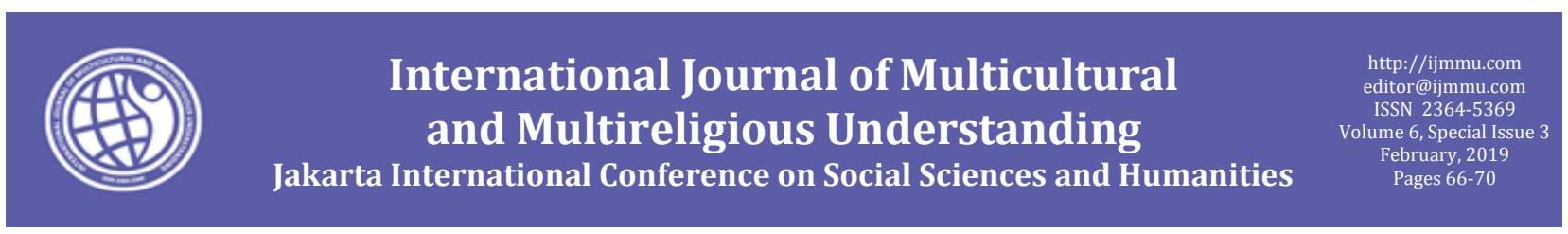

\title{
Indonesia Political Development: Democracy, Political Parties in the Political Education Perspective
}

\author{
Budi Kurniadi
}

Universitas Langlangbuana, Indonesia

\begin{abstract}
This research paper was aims to explore the dimensions of the political development that are closely related to the existence of a political system that is confronted with progressive social and political changes. Democracy as the pillar of the implementation of constitutional government is a form of political development idealism which in its implementation moves dynamically and synergizes with the prevailing political system. As one manifestation of democratic implementation, political institutionalization is the most important part in the implementation of democratic governance. The role of political parties in all countries including in Indonesia, in the plain view, coloring the political dynamics of the government. Understanding political development certainly will not be separated from the social transformation, because social changes that was occur in society also move rapidly, but on the other hand the reality of public political education is not in line with the political changes that occur due to the swift external factors including the development of foreign politics. In this critical study, certainly not all dimensions of political development will be discussed but try to express the ideas was related to democracy, political parties in the perspective of political education which includes democracy, political parties and the problem, the reality of public political education. the link between democracy, political parties and political education is at the core of this study.
\end{abstract}

Keywords: Democracy; Political Parties; Political Education

\section{Introduction}

The dynamics of Indonesian politics in its various dimensions both those that occur in the supra and infra political structures directly or indirectly affect the implementation of a democratic political system. The democratization process in the implementation of an open system ${ }^{1}$ is highly dependent on the extractive, distributive, regulative, responsive, symbolic and domestic and international capabilities of a political system, in responding to situations that develop and counteract the swift external influences of

\footnotetext{
${ }^{1}$ Gabriel A Almond,.The study of polical culturedalam Dirk Berg-schlosse and Ralf Rytlewsky,eds., Political Culture in Germany (New York :St. Martins Press,Inc.,1993)
} 
the international political constellation what happens today. The transformation of democracy in Indonesia has a long journey and from time to time the meaning of democracy is certainly not the same. This different meaning of the democracy occurs due to the real situation and conditions of state life, besides the paradigm shift about the substance of material and formal democracy, but in terms of principle it is not different ${ }^{2}$ from the goal of realizing better democracy in line with the demands of the constitution.

\section{Overview of the Democracy}

To obtain legitimacy is carried out through competitive general elections. This election is chosen at regular intervals, and voters can choose with several alternatives. In practice there are at least two political parties that have the opportunity to win so that the election is truly meaningful; 3) Some adults can participate in the electoral process, both as voters and candidates elected to important positions; 4) Residents choose confidentially and cannot be forced; 5) Communities and leaders have basic rights, such as freedom of speech, organization and freedom of the press ${ }^{3}$. Both the old political party and the new political party can try to get support for it.

Furthermore, to guarantee the democratic process the people's political participation needs to be guaranteed through the opportunity to:

1. Formulate your own preferences or interests

2. Informing about his preferences to fellow the citizens and to the government through individual and collective actions.

3. Make sure that the interests are considered equally in the government's decision-making process, meaning that they are not discriminatory based on the content and origin ${ }^{4}$.

The essence of empirical democracy, of course, is closely related to accountability, competition, involvement and high and low levels to enjoy the basic people's rights such as the right to expression, association, assembly and so on. In the developing countries with a transitional political system, the characteristics and forms of democracy are practiced in harmony with the level of development of the people who are seeking and creating identities for the good of their people ${ }^{5}$.Among these characteristics, what stands out among them is the dominant executive role in developing the identity of a shared life and when formulating development policies with various dimensions. With the strong executive intervention in the community, on the one hand it seems to have succeeded in increasing growth, but on the other hand infra political structures have little role and only as supporters because dominative power rather than consensus.

In relation to democracy in the life of the nation and state in Indonesia, some things that need attention are:

1. The belief that the condition of society is constantly changing and moving in a more advanced direction.

2. Belief that changes in society occur because of the encouragement of human actions and therefore humans can and must do to form a more advanced situation.

3. Belief that in community and state life there must be tolerance, concession and mutual giving. In this connection there must be a willingness to give credence (mandate) to other parties to exercise power or leadership within a certain period of time.

\footnotetext{
${ }^{2}$ Miriam Budiardjo,1998. Dasar-dasarllmuPolitik.,PTGramedia Jakarta : PustakaUtama, page 50

${ }^{3}$ Afan Gafar,1991., ProfilBudayaPolitik Indonesia, Jakarta : Grafiti, page 153

${ }^{4}$ Dahl, A, Robert, 1978.Modern Political Analysis, Third Edition, Prentice-Hall Inc., Englewood Cliffs, page 2-3

${ }^{5}$ AfanGafar, Ibid page 153
} 
4. Belief in the truth of common sense, which is ultimately the common sense that will achieve victory over unhealthy reason.

Starting from these four elements, the meaning of democracy in Indonesia contains various consequences which result in the need for balance as follows:

1. Balance between the interests of individuals and the interests of society

2. Balance between the dimensions of permanent physical and spiritual life of humans.

3. Balance between interactive values (religion, politics, morals, ethics, norms and so on) and disintegrative values (science, technology, economics, ethics and so on). The value of religion has an important meaning in uniting people who adhere to beliefs. Thus politics and ideology unite humans in one group. Economic values, science and technology are values that separate as well as aesthetics because one's view of what is good and bad, beautiful and not beautiful cannot be united.

4. Balance between goals and ways to achieve goals. The human goal of achieving happiness and of course in achieving it requires balance with ways to achieve it.

5. The balance between independence and justice, namely independence which guarantees justice and justice that guarantees independence. Thus the importance is not just independence, because independence must have a limit because freedom without limits will violate justice.

The rhythm of the democracy in Indonesia for 73 years of independence, in practice still leave a variety of basic problems facing the nation including increasing the economy of a pluralistic society and building a more democratic social political life. The problem of this nation basically revolves around the system and political leadership in the framework of nation building, which involves people's participation, political education for the sake of national unity and unity and avoiding the emergence of "dictators" of either individuals, political parties or the military.

\section{Political Parties and the Problem}

The Political parties as the drivers of the upholding of democracy are means for citizens to participate in the process of managing the state and the means to achieve goals which lead to the mastery of political positions for the elite members of the political parties.Political parties with their dynamics give color to the ups and downs of democracy in Indonesia, which triggers the emergence of various views in their existence. Incrementally arrangements that bind political parties are always revised as a response to socio-political changes and are more political for the continuation of political interests. This policy revision is carried out periodically, especially ahead of the democratic party and this is not new. The process of innovation, imitation, adoption and even intervention in the formulation of policies of ideal political parties is indeed important, but should be balanced with the appearance of a significant political party as a driver of change that gives birth to quality national leaders, but if examined political parties do not lead to becoming parties member even political orientation is external in terms of the determination of prospective national leaders for contestation and electoral competition. This shows that internally political parties have weaknesses in forming reliable political member who are prepared as leaders of the nation.

The change in orientation of the party's external political parties is indeed a logical consequence of an open party, but internally it implies a fundamental problem for the solidity of party member which often triggers conflicts and divisions and entrust against party leaders and administrators. On the other hand, the attitude of entrust grows in the community as a reflection of the attitude of the political elite in representative institutions and behavior that violates political and legal ethics. Then when examined about the reality of the existence of infra-structure of political parties in such a limited and inadequate area, the party secretariat is like an empty house even though it is the same as the people's house for aspirations to be fought through by factions in representative institutions. The lack of the power in this party structure is 
a general phenomenon and reality that is happening now. The dynamics of party activities are seasonal and only appear before and during democratic parties (elections/post-conflict local elections). This empirical fact as one indication of the function of political parties is not optimal. The function of the political parties refers to political partyactivities that are ideal as a means of political communication, political socialization, political recruitment, political education, conflict control, political participation and the political control. These functions should be elaborated into the party activities which are not only the decoration of documents written in silence, but only knowing but absolutelymust be understood and elaborated, implemented in the form of a real party program for the progress and welfare of the community.

Portraits of political parties like this are far from the expectation that political parties as representations of ideas that are worth fighting for are coupled with the rampant behavior of corrupt political elites, money politics, views on parties that are less pro-people, sources of problems and corruption and conflict, prioritizing interests parties and supporting wing organizations and are considered not to have a vision and mission that is clearly associated with reality. This certainly adds to the burden of the struggle for political parties to emerge as the people's chosen political party.

\section{Reality of Community Political Education}

In the terminology of the political science, political education is known as a political forming. It is called "forming" because it contains the intention of forming a political person who is aware of his political position in the community in line with Hajer's opinion which states political education as an effort to shape human beings into partisans who are politically responsible, while other opinions state that political education is a form of adult education the way to prepare cadres for political battles and get political solutions, so that they win in the political struggle and form a deliberate and systematic effort to form individuals to be able to become partisans who are ethically or morally responsible in achieving political goals. Thus the core of political education is understanding the political aspects of each problem and this political understanding can also be interpreted as understanding conflict. Many conflicts that occur in the community are caused by controversy, differences in human thoughts and actions in society, besides being caused by equality of desires and behavior, thus triggering competition, competition and conflict.

Living in a society is living in the midst of the dimensions of conflict and tension, while doing politics means influencing and participating in making decisions in the political field and fighting those conflicts.In the context of political parties, political education aims to prepare political cadres who are able to function in political battles, conflict resolution in accordance with the established political concept. Political education should be carried out by political parties regularly, programmed and structured and measured so that information can be channeled, insights and political skills are weighted and able to be critical and able to reorient their own circumstances and environmental conditions. Thus political education encourages people to see themselves and their environment in other ways, to do something else to escalate themselves and improve the standard of living of their people. The nature of political education is certainly not indoctrinative which will give birth to stiff, fanatical, narrow-minded, ignorant and chaotic people caused by their behavior which often opposes their own conscience and the reality they face, and defies general will and aspirations.

If the political education is carried out well and systematically it can grow democratic and positive counter-counter forces, as well as critical forces in fighting unhealthy situations, conditions that are not fair in realizing better and more democratic social conditions and climate. Political education for the people now reflects a lack of attention and even tends to be ignored by political parties and in fact the understanding of politics comes only from political experience and formal education as a specialization option. This neglect of the political education makes the people, individuals, clients, relatively few citizens 
who are able to understand and interpret conflict-ridden socio-political situations, lack the courage to express constructive criticism of the unstable condition of society, activities are less directed at the true democratic process and even counter-productive and unable to fight for interests and ideology especially those that correlate with security and prosperity together, lack the attention to the human role of each individual as a citizen, lack of developing all talents and abilities (knowledge, insights, attitudes, skills etc. ), so that they can actively participate in the political process for the benefit of the nation and state.

In the context of the democracy in Indonesia, political education is a pillar of political development to create awareness of the nation and state in upholding the preservation of Pancasila and the 1945 Constitution as a constitutional philosophy and foundation. What is important about political education for the people and young generation of Indonesia that is unique and comes from the national personality, for the sake of the establishment of the Unitary State of the Republic of Indonesia, because through political education.

\section{References}

AlfiandanSjamsuddin, Nazaruddin (1991). ProfilBudayaPolitik Indonesia , Jakarta : Grafiti

Almond A, Gabriel. (1993). The study of polical culturedalam Dirk Berg-schlosse and Ralf Rytlewsky,eds., Political Culture in Germany (New York :St. MartinsPress,Inc

Dahl, A, Robert. (1978). Modern Political Analysis, Third Edition, Prentice-Hall Inc., Englewood Cliffs.

Miriam Budiardjo, Miriam. (1998). Dasar-dasarIlmuPolitik.,PTGramedia Jakarta : PustakaUtama

Hajer,R. (1972). PolitiekeVorming, Walters Noordhof, Groningen,in : Brink Evvy

Kartini,kartono .(1989). Pendidikan PolitikSebagaibagiandariPendidikan Orang Dewasa, ,Bandung : MandarMaju

\section{Copyrights}

Copyright for this article is retained by the author(s), with first publication rights granted to the journal.

This is an open-access article distributed under the terms and conditions of the Creative Commons Attribution license (http://creativecommons.org/licenses/by/4.0/). 